\title{
Quantitation of IgG and IgM Human Anti-Mouse Antibodies (HAMA) Interference in CA 125 Measurements Using Affinity Chromatography
}

\author{
Norbert P. Koper ${ }^{1,3}$, Chris M. G. Thomas ${ }^{1,2}$, Leon F. A. G. \\ Massuger ${ }^{1}$, Martin F. G. Segers ${ }^{2}$, André J . Olthaar ${ }^{2}$ and \\ André L. M. Verbeek ${ }^{3,4}$ \\ ${ }^{1}$ Department of Obstetrics and Gynaecology \\ ${ }^{2}$ Laboratory of Endocrinology and Reproduction \\ ${ }^{3}$ Department of Epidemiology, \\ University of Nijmegen, Nijmegen, The Netherlands \\ ${ }^{4}$ The Comprehensive Cancer Centre IKO, Nijmegen, The \\ Netherlands
}

Currently no available immunoassay system offers complete protection against spuriously elevated or lowered results due to interference by Human AntiMouse Antibodies (HAMA). Although routine use of chromatography procedures is not an acceptable option because of the extra cost and workload involved, such a procedure would be highly desirable to ensure accurate immunoassay results. The present report describes a relatively simple affinity chromatography procedure using a HiTrap Protein G column to isolate immunoglobulin G (IgG) HAMA, followed by a HiTrap N-hydroxy-succinimide(NHS)-activated column coupled to goat-anti human immunoglobulin M (IgM) to bind IgM HAMA. To examine the usefulness of this purification procedure we determined CA 125 in forty serum samples prior to and following chromatography. Pre- and post-injection samples were obtained from 20 patients injected with $1 \mathrm{mg}$ of ${ }^{111}$ In-labelled murine OC $125 \mathrm{~F}\left(a b^{\prime}\right)_{2}$ fragments in an immunoscintigraphy study.

It is shown that this analytical procedure provides a technique to determine the extent and the nature of the existing HAMA interference in samples of patients after in vivo use of monoclonal antibodies for diagnostic or therapeutic purposes. The procedure can also contribute to the clarification of clinically discordant CA 125 results. Finally, the availability of such a procedure in the clinical laboratory provides an opportunity to test the robustness of newly developed immunoassay systems towards HAMA interference.

Key words: Human Anti-Mouse Antibodies (HAMA); CA 125; Chromatography; Heterophilic antibody interference.

\section{Introduction}

Heterophilic antibodies comprise human immunoglobulins directed against antigenic determinants from non-human species. Agents causing development of such heterophilic antibodies may originate either from natural sources (like nutritional or agricultural factors) or following injection of mouse monoclonal antibodies for diagnostic or therapeutic purposes, the latter possibly leading to development of Human Anti-Mouse Antibodies (HAMA) (1-3). The development of HAMA is well known to influence both in vivo and in vitro diagnostic applications of monoclonal antibodies. For instance, diagnostic testing kits designed for the quantitation of tumour markers in serum are not guaranteed against unexpected interferences emerging from HAMA present in the serum samples under consideration. Consequently, many attempts have been undertaken to develop analytical procedures to eliminate these undesired interferences caused by HAMA present in a given specimen. At least four different approaches have been reported, each of which has limitations in terms of general applicability, laboriousness, or costs. The most widely used methods to protect assay systems from HAMA interference are:

1. the addition of blocking reagents (i. e., whole murine serum or immunoglobulins) to the incubation medium $(4,5)$;

2. the development of heterologous double determinant two step sandwich type immunoassays using different monoclonal or polyclonal antibodies as capture and tracer (6);

3. the combination of non-murine polyclonal with murine monoclonal antibodies in a single assay (7-9); and

4. the removal of HAMA by chromatography $(10,11)$.

The first three methods have been used to a certain extent in the development of the second generation CA 125 assay systems. However, HAMA interferences can still occur (12). Chromatography of serum specimens before immunoassay could be used to circumvent this problem of incomplete protection against HAMA (10, $11)$, but such a procedure should preferably be simple. Thus, we developed a straightforward chromatography procedure which can be used

1. to determine the extent of HAMA response in serum specimens with unexpected or clinically unexplained immunoassay results and

2. to test the robustness of newly developed assay systems against HAMA interferences.

The aim of the present report is to describe this relatively simple chromatography procedure and to illustrate its use by presenting results from patients who were participating in an immunoscintigraphy study. The availability of such a procedure in a clinical tumour marker laboratory is of growing importance considering the possible increase in the occurrence of HAMA positive serum samples due to increased clinical application of murine antibodies (5). 


\section{Patients and Methods}

\section{Patients}

Patients suspected of having ovarian cancer were injected iv with $1 \mathrm{mg}$ of ${ }^{111} \mathrm{In}$-labelled murine $\mathrm{OC} 125 \mathrm{~F}\left(\mathrm{ab}^{\prime}\right)_{2}$ fragments, the monoclonal antibody against the CA 125 determinant, in an immunoscintigraphy study. Blood samples were taken prior to, as well as three or more weeks after, injection and centrifuged for 10 minutes at $2000 \times g$. Serum specimens were stored at $-35^{\circ} \mathrm{C}$ until assayed. For the present study serum samples from 20 patients were used, of whom ten patients demonstrated HAMA development following injection of the antibody fragment.

\section{Methods}

CA 125 was determined in all specimens using two different assay procedures. The first assay used was the Abbott CA 125 RIA (Abbott Laboratories, Chicago, IL, USA). This was a double determinant 'sandwich-type' immunoradiometric assay using OC 125 mouse monoclonal antibody coated beads as capture and ${ }^{125}$-labelled OC 125 mouse monoclonal antibody as tracer. The kits were used according to the manufacturer's instructions. The assay system was identical to the 'first generation' Centocor RIA I assay system, and was partly protected against HAMA interference. This assay system was widely used until it was replaced by the 'second generation' CA 125 II system. The minimum detectable concentration of this assay was determined to be $7.6 \mathrm{kU} / \mathrm{l}$. As a measure of precision we calculated the within- $\left(\mathrm{CV}_{\mathrm{w}}\right)$ and between-assay $\left(\mathrm{CV}_{\mathrm{b}}\right)$ coefficients of variation for means of duplicate measurements from a pool of serum in 15 consecutive assay runs. At a mean serum concentration of $50 \mathrm{kU} / \mathrm{l}$, the Abbott CA $125 \mathrm{RIA}$ demonstrated $\mathrm{a} \mathrm{CV}_{\mathrm{w}}$ of $7.1 \%$ and $\mathrm{a} \mathrm{CV}_{\mathrm{b}}$ of $11 \%$.

The second assay used was an OC $125 \mathrm{~F}\left(\mathrm{ab}^{\prime}\right)_{2}$-based double determinant 'sandwich-type' immunoradiometric assay using OC $\left.125 \mathrm{~F}(\mathrm{ab})_{2}\right)_{2}$ (mouse) coated microtitreplate wells as capture site and ${ }^{125}$-labelled $\mathrm{OC} 125 \mathrm{~F}\left(\mathrm{ab}^{\prime}\right)_{2}$ as a tracer. No attempt was made to protect this assay from HAMA interference. This assay was developed in this laboratory ('In-House'(IH)) and the procedure was essentially the same (except for label and antibody) as described previously by Boerman et al. (13). This assay will be referred to as the 'IH CA 125 RIA'. In brief, $100 \mu$ l of serum, $100 \mu \mathrm{l}$ of phosphate buffered saline $(42 \mathrm{mmol}$ of $\mathrm{Na}_{2} \mathrm{HPO}_{4} \cdot 2 \mathrm{H}_{2} \mathrm{O}, 7.9 \mathrm{mmol}$ of $\mathrm{K}_{2} \mathrm{HPO}_{4}(\mathrm{pH} 7.35), 154 \mathrm{mmol} \mathrm{NaCl}$, $5.0 \mathrm{~g}$ of acid free bovine albumin, and $31 \mathrm{mmol} \mathrm{NaN}_{3}$ per litre), and $10 \mu \mathrm{l}$ of ${ }^{125}$-labelled $\mathrm{OC} 125 \mathrm{~F}\left(\mathrm{ab}^{\prime}\right)_{2}(600 \mu \mathrm{g} / \mathrm{ll})$ as a tracer were added to ${ }^{125}$-labelled OC $125 \mathrm{~F}\left(\mathrm{ab}^{\prime}\right)_{2}$-coated 12well strips (Immulon-1 removawell strips, Dynatech Laboratories, Chantilly, VA, USA). After overnight incubation at room temperature the wells were washed three times and after breaking off each well from the microtitre strip ${ }^{125}$ /-radioactivity was measured in each well in a $\gamma$-scintillation counter (Wallac Oy, Turku, Finland). We determined $7.0 \mathrm{kU} / \mathrm{l}$ as the lower detection limit of IH CA 125 RIA in our laboratory. After measurement of a serum pool (mean: $48 \mathrm{kU} / \mathrm{l}$ ) in 15 consecutive assay runs, the $\mathrm{CV}_{\mathrm{w}}$ for means of duplicate measurements was $8.1 \%$ and the corresponding $\mathrm{CV}_{\mathrm{b}} 15 \%$.

To calibrate the IH CA 125 RIA assay we constructed a standard curve using the CA 125 standard material included in the Abbott CA 125 RIA. Comparison of the results of the two assay systems was made by calculation of the regression line according to Passing \& Bablok (14). Using fifteen serum samples in the concentration range between 7.0 and $17000 \mathrm{kU} / \mathrm{l}$ tho following regression equation was found:

IH CA 125 RIA $=0.994 \times$ Abbott CA $125 \mathrm{RIA}+0.022 \mathrm{kU} / \mathrm{l}$.
Prior to chromatography, all samples were assayed with the two assay systems used. Next, affinity chromatography was performed to isolate HAMA and to determine the subclass (IgG and/or IgM) of the HAMA present in the specimen. The flow-chart of the HAMA isolation by affinity chromatography is shown in Figure 1. After each chromatography step CA 125 activity was determined in the effluent fraction as well as in the eluted fraction by using the IH CA 125 RIA. To isolate the IgG fraction a HiTrap Protein G column (1 ml, Pharmacia, Uppsala, Sweden) was used. In brief, $250 \mu \mathrm{l}$ of serum and $250 \mu \mathrm{l}$ of $0.02 \mathrm{~mol}$ phosphate buffer, $\mathrm{pH}$ 7.0, were applied to the HiTrap Protein G column. Using the same phosphate buffer, a total effluent fraction was collected at a flow rate of $0.5 \mathrm{ml} / \mathrm{min}$. Due to the 4-fold sample dilution of the effluent fraction, the CA 125 concentrations as determined with the IH CA 125 RIA assay could be quantitated with a minimum detectable concentration of $28 \mathrm{kU} / \mathrm{l}$. The bound IgG was eluted with $1 \mathrm{ml}$ of $0.1 \mathrm{~mol}$ glycine- $\mathrm{HCl}$ buffer ( $\mathrm{pH}$ 2.7). Immediately after elution the $\mathrm{pH}$ was neutralized using $50 \mu \mathrm{l}$ of $1 \mathrm{~mol}$ Tris- $\mathrm{HCl}(\mathrm{pH}$ 9.0). The isolated IgG HAMA in the 4.2-fold diluted eluent fraction was quantitated in terms of apparent CA 125 concentrations as measured with the IH CA 125 RIA. Thus, the minimal detectable concentration of IgG HAMA as determined with the IH CA $125 \mathrm{RIA}$ was $29 \mathrm{kU} / \mathrm{l}$

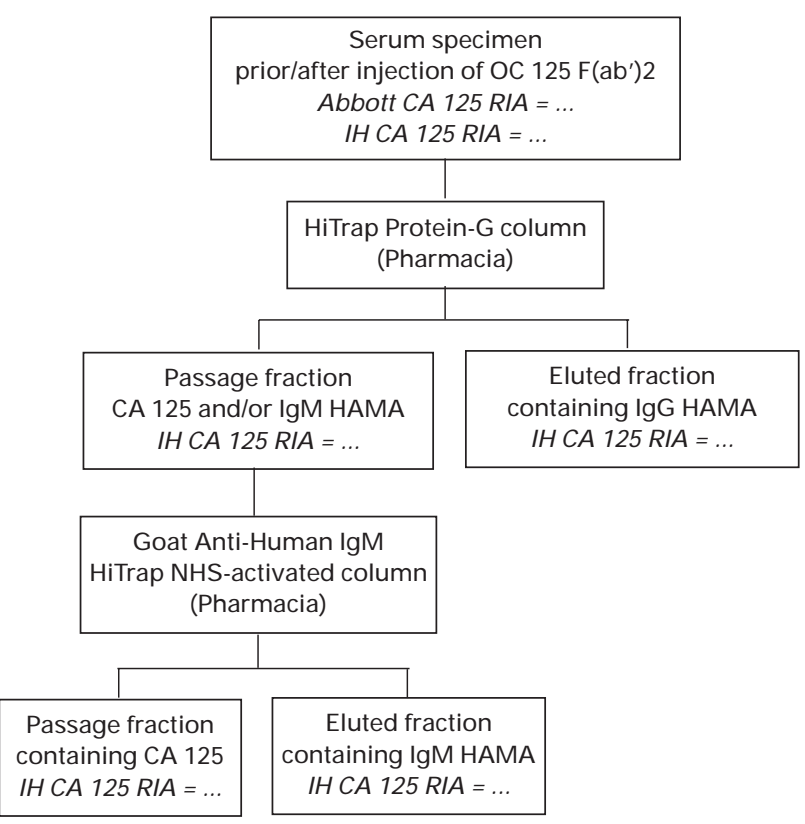

Fig. 1 Flow-chart of Human Anti-Mouse Antibodies (HAMA) isolation by affinity chromatography.

Next, $500 \mu \mathrm{l}$ of the Protein G column effluent fraction were applied to a goat-anti-human IgM coupled, HiTrap NHS-activated column (1 ml, Pharmacia, Uppsala, Sweden), according to the manufacturer's instructions. Using the same phosphate buffer as for the development of the Protein G column, a total effluent fraction of $1 \mathrm{ml}$ was collected at a flow rate of $0.5 \mathrm{ml} / \mathrm{min}$. Due to an 8-fold sample dilution, the minimum detectable concentration of IH CA 125 RIA in the final effluent was $56 \mathrm{kU} / \mathrm{l}$. The bound IgM was eluted using the same procedure as described for IgG. The IgM HAMA present in this elution fraction could be determined with a minimum detectable concentration of $59 \mathrm{kU} / \mathrm{l}$ by using the IH CA 125 RIA, and is expressed in terms of apparent CA 125. The IH CA 125 RIA determinations in all the eluent and effluent fractions were done using $100 \mu \mathrm{l}$ of such a fraction together with $100 \mu \mathrm{l}$ of foetal calf serum (Hyclone Laboratories, Logan, UT, USA) to compensate for the lack of a serum matrix. The accuracy of the affinity 
chromatography procedure was tested by calculating the procedural losses over the entire chromatographic work up. In the case of nine pre-treatment (i. e. HAMA-free) samples the mean recovery percentage of the IH CA 125 RIA results after chromatography was calculated to be $70 \%(S D=12 \%)$. Testing of ten HAMA-negative postinjection serum samples revealed a mean recovery of $68 \%(S D=24 \%)$.

The results are grouped according to the IH CA 125 RIA concentrations as measured after completion of the two chromatography steps, depending on the presence of detectable CA 125 and/or IgG or IgM HAMA. To summarize the data and quantify the extent of HAMA interference, several ratios were calculated and the mean ratios and their $95 \%$ confidence intervals ( $95 \% \mathrm{Cl}$ : mean $\pm 1.96 \times \mathrm{SE}$ ) are presented. We first calculated the ratio of CA $125 \mathrm{Abbott}$ and IH determinations prior to chromatography (ratio of 'gross' concentrations) to assess the influence of HAMA on assay results obtained with the two CA 125 assay systems used. This ratio depicts the comparability of both assay systems. After removal of IgG and/or IgM HAMA by chromatography 'net' IH CA 125 concentrations were determined. To quantify the HAMA interference the Abbott-gross//H-net ratio and the $\mathrm{IH}$-gross/lH-net ratio were calculated. A higher ratio indicates a larger interference by HAMA because the net concentrations determined after chromatography are lower compared to the gross concentrations determined before HAMA removal by chromatography.

Tab. 1 CA 125 results of serum specimens in which no IgG or IgM HAMA could be determined (above the minimum detectable concentrations) following chromatography. Specimens

\section{Results}

Tables 1 and 2 depict all assay results, which are grouped according to the presence of detectable CA 125 and/or HAMA, as determined with the IH CA 125 RIA assay after the two chromatography steps.

The calculated mean CA 125 Abbott-gross/lH-gross ratio of the specimens with no detectable HAMA (tab. 1; groups 1 and 2) was 1.16 (95 \% Cl: 1.02-1.30), while the mean Abbott-gross/lH-net ratio was 1.69 (95\% Cl: 1.38-2.0). Thus, on average the Abbott CA 125 results were somewhat higher compared to the IH CA 125 RIA results. The higher ratio after chromatography was due to lower $\mathrm{IH}$-net results. This could also be inferred from the IH-gross/lH-net ratio which was 1.46 (95\% Cl: 1.26-1.66) with these samples. All specimens comprising group 1 showed detectable CA 125 concentrations after chromatography, meaning that these are true positive CA 125 results. However, no CA 125 could be detected after chromatography in the five samples comprising group 2. However, this may be due to the increased limit of detection caused by the dilution steps of the chromatography procedure. Neither IgG nor IgM HAMA above the minimum detectable concen-

were collected pre-injection (week -1) and several weeks postinjection of ${ }^{111}$ In-labelled murine $\mathrm{OC} 125 \mathrm{~F}\left(\mathrm{ab} \mathrm{b}_{2}\right)_{2}$ fragments. All determinations are expressed in $\mathrm{kU} / \mathrm{l}$.

\begin{tabular}{|c|c|c|c|c|c|c|c|}
\hline \multirow[t]{3}{*}{$\begin{array}{l}\text { Patient } \\
\text { No. }\end{array}$} & \multirow[t]{3}{*}{ Week } & \multicolumn{2}{|c|}{$\begin{array}{l}\text { Prior to } \\
\text { chromatography } \\
\text { ('gross') }^{1}\end{array}$} & \multirow{2}{*}{\multicolumn{2}{|c|}{$\begin{array}{l}\text { After lgG column } \\
\text { chromatography }\end{array}$}} & \multirow{2}{*}{\multicolumn{2}{|c|}{$\begin{array}{l}\text { After IgM column } \\
\text { chromatography } \\
(\text { ('net') })^{2,3} \\
\text { IH RIA }\end{array}$}} \\
\hline & & \multirow{2}{*}{$\begin{array}{l}\text { Abbott RIA } \\
\text { CA } 125\end{array}$} & \multirow{2}{*}{$\begin{array}{l}\text { IH RIA } \\
\text { CA } 125\end{array}$} & & & & \\
\hline & & & & CA 125 & $\operatorname{IgG}$ HAMA & CA 125 & $\operatorname{Ig} M$ HAMA \\
\hline \multicolumn{8}{|c|}{ it no detectable HAMA after chromatography } \\
\hline 1 & 3 & 120 & 170 & 110 & $<29$ & 88 & $<59$ \\
\hline 1 & 6 & 380 & 210 & 140 & $<29$ & 120 & $<59$ \\
\hline 2 & -1 & 2900 & 2200 & $>2000^{4}$ & $<29$ & 1700 & $<59$ \\
\hline 2 & 3 & 150 & 170 & 96 & $<29$ & 90 & $<59$ \\
\hline 2 & 6 & 340 & 410 & 200 & $<29$ & 240 & $<59$ \\
\hline 3 & -1 & 3000 & 2400 & 1500 & $<29$ & 1600 & $<59$ \\
\hline 3 & 3 & 2800 & 2100 & 1300 & $<29$ & 1400 & $<59$ \\
\hline 3 & 6 & 3000 & 2200 & 990 & $<29$ & 750 & $<59$ \\
\hline 6 & -1 & 300 & 190 & 160 & $<29$ & 110 & $<59$ \\
\hline 7 & -1 & 1300 & 1300 & 1200 & $<29$ & 1200 & $<59$ \\
\hline 7 & 3 & 400 & 210 & 140 & $<29$ & 190 & $<59$ \\
\hline 8 & -1 & 390 & 390 & 300 & $<29$ & 260 & $<59$ \\
\hline 8 & 3 & 360 & 330 & 300 & $<29$ & 210 & $<59$ \\
\hline 9 & -1 & 1100 & 900 & 780 & $<29$ & 420 & $<59$ \\
\hline 10 & -1 & 1400 & 1400 & 1200 & $<29$ & 940 & $<59$ \\
\hline 13 & -1 & 14000 & 17000 & 9200 & $<29$ & 9800 & $<59$ \\
\hline 15 & 7 & 190 & 140 & 140 & $<29$ & 110 & $<59$ \\
\hline 20 & -1 & 170 & 190 & 120 & $<29$ & 160 & $<59$ \\
\hline 20 & 5 & 370 & 390 & 280 & $<29$ & 390 & $<59$ \\
\hline \multicolumn{8}{|c|}{ Group 2: No detec } \\
\hline 15 & -1 & 89 & 68 & 40 & $<29$ & $<56$ & $<59$ \\
\hline 15 & 4 & 76 & 76 & 39 & $<29$ & $<56$ & $<59$ \\
\hline 16 & -1 & 43 & 64 & 41 & $<29$ & $<56$ & $<59$ \\
\hline 19 & 2 & 31 & 34 & $<28$ & $<29$ & $<56$ & $<59$ \\
\hline 19 & 9 & 45 & 28 & $<28$ & $<29$ & $<56$ & $<59$ \\
\hline
\end{tabular}

${ }^{1}$ Abbott-gross/lH-gross ratio: $\mathrm{n}=24$, mean $=1.16(95 \% \mathrm{Cl}: 1.02-1.30) \quad{ }^{3} \mathrm{IH}$-gross/lH-net ratio: $\mathrm{n}=24$, mean $=1.46$ (95 \% Cl: $\left.1.26-1.66\right)$

2 Abbott-gross/lH-net ratio: $\mathrm{n}=24$, mean $=1.69(95 \% \mathrm{Cl}: 1.38-2.0) \quad{ }_{4}^{4}$ Too little specimens available for reanalysis after dilution 
Tab. 2 CA 125 results of serum specimens in which IgG and/ or IgM HAMA could be determined (above the minimum detectable concentrations) following chromatography. Speci- mens were collected pre-injection (week -1) and several weeks post-injection of ${ }^{111}$ In-labelled murine OC $125 \mathrm{~F}\left(\mathrm{ab}^{\prime}\right)_{2}$ fragments. All determinations are expressed in $\mathrm{kU} / \mathrm{l}$.

\begin{tabular}{|c|c|c|c|c|c|c|c|}
\hline \multirow[t]{3}{*}{$\begin{array}{l}\text { Patient } \\
\text { No. }\end{array}$} & \multirow[t]{3}{*}{ Week } & \multicolumn{2}{|c|}{$\begin{array}{l}\text { Prior to } \\
\text { chromatography } \\
(\text { 'gross') })^{1}\end{array}$} & \multirow{2}{*}{\multicolumn{2}{|c|}{$\begin{array}{l}\text { After IgG column } \\
\text { chromatography }\end{array}$}} & \multirow{2}{*}{\multicolumn{2}{|c|}{$\begin{array}{l}\text { After IgM column } \\
\text { chromatography } \\
(\text { 'net') })^{2,3} \\
\text { IH RIA }\end{array}$}} \\
\hline & & \multirow{2}{*}{$\frac{\text { Abbott RIA }}{\text { CA } 125}$} & \multirow{2}{*}{$\begin{array}{l}\text { IH RIA } \\
\text { CA } 125\end{array}$} & & & & \\
\hline & & & & CA 125 & IgG HAMA & CA 125 & $\operatorname{Ig} M$ HAMA \\
\hline \multicolumn{8}{|c|}{ dd detectable HAMA after chromatography } \\
\hline 5 & 3 & 1700 & 33000 & 2400 & 4800 & 730 & 540 \\
\hline 6 & 3 & $>5000^{4}$ & 33000 & 2400 & 17000 & 190 & 920 \\
\hline 11 & 3 & 68000 & 150000 & 3400 & 25000 & 290 & 590 \\
\hline 11 & 6 & 44000 & 130000 & 1700 & 27000 & 290 & 1300 \\
\hline 13 & 3 & 18000 & 32000 & 15000 & 110 & 14000 & 250 \\
\hline 13 & 6 & 22000 & 38000 & 22000 & 970 & 15000 & 700 \\
\hline 14 & 3 & 270 & 1600 & 1200 & 430 & 61 & 220 \\
\hline 16 & 4 & 2300 & 16000 & 8600 & 1500 & 1800 & 2600 \\
\hline 16 & 6 & 5000 & nd & 16000 & 5600 & 1800 & 3600 \\
\hline 17 & 4 & 1000 & nd & 6800 & 3700 & 170 & 1800 \\
\hline 18 & 11 & 330 & 960 & 590 & 82 & 170 & 67 \\
\hline \multicolumn{8}{|c|}{ Group 4: No dete } \\
\hline 4 & 3 & 2300 & 4500 & 290 & 1300 & $<56$ & 290 \\
\hline 12 & 3 & 290 & 1700 & 2000 & 420 & $<56$ & 290 \\
\hline 12 & 6 & 200 & 1000 & 1100 & 180 & $<56$ & 220 \\
\hline 14 & 6 & 430 & 1200 & 260 & 650 & $<56$ & $<59$ \\
\hline 18 & 3 & 54 & 2300 & 540 & 150 & $<56$ & 290 \\
\hline
\end{tabular}

${ }^{1}$ Abbott-gross/lH-gross ratio: $\mathrm{n}=14$, mean $=0.29$ (95 \% Cl: 0.19-0.39)

2 Abbott-gross/lH-net ratio: $\mathrm{n}=16$, mean $=31(95 \% \mathrm{Cl}: 0-63)$
3 IH-gross/IH-net ratio: $\mathrm{n}=14$, mean $=102$ (95\% Cl: 14-190)

4 Too little specimens available for reanalysis after dilution nd Not done trations was found in either of these samples in groups 1 and 2. Thus, the CA 125 concentrations from these samples could be considered accurate results.

The two groups in which HAMA was present (Tab. 2: groups 3 and 4) showed an Abbott-gross/lH-gross ratio of 0.29 (95\% Cl: 0.19-0.39). This low ratio results from the much higher apparent CA 125 values determined with the HAMA-unprotected IH assay as compared to the Abbott assay results, which is (at least partly) HAMA protected. The Abbott-gross/IH-net ratio determined after chromatography was as high as 31 (95\% $\mathrm{Cl}$ : 0-63) illustrating unequivocal interference of the Abbott CA 125 results by the presence of IgG and IgM HAM A. Likewise, the $\mathrm{IH}$-gross/IH-net ratio was raised to 102 (95\% Cl: 14-190). In the samples comprising group 3, CA 125 could still be detected after chromatography. The CA 125 activity originating from the IgG and IgM fractions present in the sample, however, did account for most of the CA 125 measured before chromatography. This was even more prominent in the serum specimens comprising group 4. After chromatography, these samples did not demonstrate any CA 125 activity above the minimum detection limit. Instead, all of the signal could be attributed to IgG and IgM HAMA present in these specimens.

\section{Discussion}

The application of murine monoclonal antibodies in immunodiagnostic assay systems necessitates the development of methods to eliminate or circumvent the undesirable interference of heterophilic antibodies. Such interferences may otherwise lead to undesirable clinical consequences such as the discontinuation of chemotherapy for ovarian cancer, or the initiation of a procedure to determine the site and extent of suspected recurrent tumour growth.

A recent report by Reinsberg discussed the suboptimal efficacy of three blocking reagents to eliminate interferences caused by HAMA in a two-site immunoassay system (5). This author showed that it was difficult to suppress all spurious increases of CA 125 by absorption of HAMA to non-specific mouse IgG or other immunoglobulin preparations. Other studies have investigated the degree of protection against HAMA interferences attained by the development of non-OC 125 antibodies, e. g. the Truquant B43.13 and B27.1 monoclonal antibodies applied in the Truquant OV2 (6), or the monoclonal antibody M11, applied in the heterologous 'second generation' CA 125 assays of various formats (7-9). These reports invariably show that it is still possible to end up with falsely elevated or lowered results, especially when one-step protocols 
are being used $(9,15)$. The development of assay systems containing non-murine (polyclonal) antibodies, e. g. Abbott IMXCA 125 containing sheep polyclonal antibodies, also did not prove to offer absolute protection from HAMA interference $(6,12)$.

The use of affinity chromatography procedures has been described previously $(10,11)$. This approach resulted in adequate separation of CA 125 and HAMA. However, considerable disadvantages such as sample dilution, additional workload, and higher costs, were also recognised (11). The presently described chromatography procedure also has some of these drawbacks. Due to sample dilution the minimal detectable concentration for IH CA 125 measurements is 4-fold increased after the first chromatography step and 8-fold following the second step. The minimal detectable concentrations for the IgG and IgM HAMA activity measured by the IH CA 125 RIA are slightly higher due to the elution process. As a result, relatively low IH CA 125 concentrations (i. e. $<56 \mathrm{kU} / \mathrm{l}$ ) such as those in group 2 could not be quantified exactly after two chromatography steps. In these samples no HAMA could be determined either. This was in contrast to group 4 (tab. 2), in which CA 125 concentrations were below the detection limit, but substantial HAMA concentrations were present. The results of groups 3 and 4 also showed that the Abbott RIA did not accurately measure CA 125 concentrations in HAMA-positive samples. Furthermore, seven samples of the specimens with no detectable HAMA (Tab. 1, group 1) showed higher IH CA 125 results after the second (IgM) chromatography procedure compared to the results after the first Ig chromatography step. In addition, two samples in group 4 (patient 12) had higher IH CA 125 results after IgG chromatography compared to the results obtained before chromatography. These findings might be attributed to analytical imprecision due to dilution, rounding off of analytical results to two significant figures, serum matrix effects, or to changing reaction kinetics of the various HAMA forms during the analytical workup procedure. However, considering the measured concentrations in these samples there is little chance that this imprecision would have resulted in a different clinical interpretation. The clinical relevance of information about the exact nature of the HAMA present (IgG or IgM) is probably rather limited. In the present studies all samples in which IgM HAMA could be determined also showed IgG HAMA. One sample (group 4, patient 14) only showed IgG HAMA. Moreover, IgG HAMA concentrations exceeded IgM HAMA concentrations in all but four cases. One may infer from these findings that IgG chromatography will be sufficient to demonstrate the presence of HAMA in a serum sample. This would enable serum CA 125 quantitations as low as $28 \mathrm{kU} / \mathrm{l}$. However, best quantitations of the serum CA 125 concentration are obtained after removal of all HAMA, including IgM type HAMA, although this can only be achieved at the cost of an increased minimum detectable concentration.

One final point to address here is that only anti-idiotypic HAMA is being considered in the present study. None of the pre-injection samples showed detectable
HAMA. Moreover, both the in vivo applied monoclonal antibody as well as the monoclonal antibody used in the IH assay system were OC $125 \mathrm{~F}\left(\mathrm{ab}^{\prime}\right)_{2}$ based. Without the FC domain present, it is unlikely that anti-isotypic HAMA has played an important role in the present study.

In conclusion, the chromatography procedure described in the present study does provide a relatively simple method to eliminate and quantify HAMA interference in CA 125 determinations. Moreover, IgG and IgM HAM A interference can be separated. Sample dilution leads to an increase in the minimum detectable concentration of CA 125 which could be of importance in samples in the concentration range below $60 \mathrm{kU} / \mathrm{l}$.

Although large scale routine use of this method is still limited by the extra workload, cost and time involved, it can be used when dealing with samples of patients suspected to show HAMA, particularly after in vivo use of monoclonal antibodies for diagnostic or therapeutic purposes. Moreover, it provides a way to reanalyse samples on request of a clinician faced with a clinically discordant assay result that might be a result of pre-existing HAMA. Furthermore, this procedure is highly suitable for testing new immunoassay systems for robustness towards HAMA interference. Testing of HAMA-positive serum samples, before and after affinity chromatography, with such a new assay system can give insight into the extent of protection towards HAMA of this new assay procedure. If available, the results of a non-protected assay system could be used as a reference method to compare several assay systems, each being more or less protected against HAMA interferences.

\section{References}

1. Howanitz PJ , HowanitzJ H, Lamberson HV, Ennis KM. Incidence and mechanism of spurious increases in serum thyrotropin. Clin Chem 1982; 28:427-31.

2. Moseley KR, Knapp RC, Haisma HJ . An assay for the detection of human anti-murine immunoglobulin in the presence of CA 125 antigen. J Immunol Methods 1988; 106:1-6.

3. Thompson RJ , J ackson AP, Langlois N. Circulating antibodies to monoclonal immunoglobulins in normal subjects: incidence, species specificity, and effects on a twosite assay for creatine kinase-MB isoenzyme. Clin Chem 1986; 32:476-81.

4. Boerman OC, Segers MFG, Poels LG, Kenemans P, Thomas CMG. Heterophilic antibodies in human sera causing falsely increased results in the CA 125 immunofluorometric assay. Clin Chem 1990; 36:888-91.

5. Reinsberg J. Different efficacy of various blocking reagents to eliminate interferences by human antimouse antibodies with a two-site immunoassay. Clin Biochem 1996; 29:145-8.

6. Reinsberg J , Schultes B, Wagner U, Krebs D. Monitoring cancer antigen 125 in serum of ovarian cancer patients after administration of ${ }^{131}$-labelled $\mathrm{F}\left(\mathrm{ab}^{\prime}\right)_{2}$ fragments of $\mathrm{OC}$ 125 antibody. Clin Chem 1993; 39:891-6.

7. J äger W, Zoller O. Human anti-mouse antibodies against OC- 125 do not interfere in a CA 125 assay that uses OC 125 and M11 antibodies [letter]. Clin Chem 1993; 39:1556- 7. 
8. Kenemans P, van Kamp GJ , Oehr P, Verstraeten RA. Heterologous double-determinant immunoradiometric assay CA 125 II: reliable second-generation immunoassay for determining CA 125 in serum. Clin Chem 1993; 39:250913.

9. Reinsberg J, Gast B. Human antiidiotypic antibodies against OC 125 strongly interfere with one-step assays of CA 125 employing OC 125 and M 11 antibodies [letter]. Clin Chem 1994; 40:951-2.

10. Newman ES, Moskie LA, Duggal RN, Goldenberg DM, Hansen $\mathrm{HJ}$. Murine monoclonal antibody absorbed onto vinylidene fluoride floccules used to eliminate antibody interference in 'sandwich'-type immunoassays. Clin Chem 1989; 35:1743-6.

11. Turpeinen $\mathrm{U}$, Lehtovirta $\mathrm{P}$, Alfthan $\mathrm{H}$, Stenman $\mathrm{U}-\mathrm{H}$. Interference by human anti-mouse antibodies in CA 125 assay after immunoscintigraphy: anti-idiotypic antibodies not neutralized by mouse IgG but removed by chromatography. Clin Chem 1990; 36:1333-8.

12. Thomas CMG, Massuger LFAG, Segers MFG, Schijf CPT, Doesburg WH, Wobbes T. Analytical and clinical performance of improved Abbott IM X CA 125 assay: comparison with Abbott CA 125 RIA. Clin Chem 1995; 41:211-6.
13. Boerman OC, Thomas CMG, Segers MFG, Kenemans $P$, Lövgren T, Zurawski VR, et al. Time-resolved immunofluorometric assay for the ovarian carcinoma-associated antigenic determinant CA 125 in serum. Clin Chem 1987; 33:2191-4.

14. Passing $\mathrm{H}$, Bablok W. A new biometrical procedure for testing the equality of measurements from two different analytical methods. Application of linear regression procedures for method comparison studies in clinical chemistry, part I. J Clin Chem Clin Biochem 1983; 21:709-20.

15. Reinsberg J , Nocke W. Falsely low results in CA 125 determination due to anti-idiotypic antibodies induced by infusion of $\left.{ }^{131} \mathrm{IF}(\mathrm{ab})_{2}\right)_{2}$ fragments of the OC 125 antibody. Eur J Clin Chem Clin Biochem 1993; 31:323-7.

\section{Received 1 September 1997; accepted 25 November 1997}

Corresponding author: N. P. Koper, University of Nijmegen, Department of Epidemiology, P. O. Box 9101, NL-6500 HB Nijmegen, The Netherlands

Tel.: +31-24-3617794, Fax: +31-24-3613505 